\title{
Relationship between Organizational Justice Dimensions and Organizational Commitment: A Mediating Mechanism of Overall Justice
}

\author{
${ }^{a}$ Shahzad Khan Durrani, ${ }^{\mathrm{b}}$ Ahmed Ullah Shah, ${ }^{\mathrm{c}}$ Shakeel Khan \\ ${ }^{a}$ Lecturer, Kohat University of Science \& Technology, Kohat, Pakistan \\ Email: shehzad.khan@kust.edu.pk \\ ${ }^{\mathrm{b}}$ Assistant Professor, Kohat University of Science \& Technology, Kohat, Pakistan \\ Email: dr.ahmed@kust.edu.pk \\ ${ }^{\mathrm{c}}$ Lecturer, University of Peshawar, Peshawar, Pakistan \\ Email: shakeel.ims@uop.edu.pk
}

\begin{tabular}{|c|c|}
\hline ART & ABSTRACT \\
\hline His & \multirow{8}{*}{$\begin{array}{l}\text { The research on organizational justice (OJ) by and large focuses on OJ } \\
\text { dimensions and their impact on employees' attitude and behaviour. } \\
\text { However, some researchers suggest an equal focus on the concept of } \\
\text { overall justice. The objective of this paper is to determine the level of } \\
\text { prevalence of OJ dimensions within private sector universities of } \\
\text { Pakistan, and to evaluate whether overall justice mediates between OJ } \\
\text { dimensions and OC. Kenny's contemporary approach to mediation was } \\
\text { used to test the mediating effect of overall justice. Our results reflect } \\
\text { that with the exception of distributive justice, remaining three } \\
\text { dimensions prevails within private sector universities. Similarly, there is } \\
\text { no direct relationship between OJ dimensions and OC, rather, this } \\
\text { relationship is best explained by incorporating overall justice in the } \\
\text { model. }\end{array}$} \\
\hline & \\
\hline Ine 2021 & \\
\hline Key & \\
\hline & \\
\hline $\begin{array}{l}\text { Distribut } \\
\text { Justice }\end{array}$ & \\
\hline $\mathrm{JE}$ & \\
\hline & \\
\hline
\end{tabular}

DOI: $10.47067 /$ real.v4i2.146

(C) 2021 The authors. Published by SPCRD Global Publishing. This is an open access article under the Creative Commons AttributionNonCommercial 4.0

Corresponding author's email address: shehzad.khan@kust.edu.pk

\section{Introduction}

Organizational justice (OJ) has been the common area of researchers' interest during the last four decades in three different fields (Colquitt, 2012; Colquitt, Conlon, Wesson, Porter, \& Ng, 2001). Thanks to all those researchers' who have developed significant literature in this area; however, there exist many theoretical gaps, issues, and inconsistencies (Rupp, 2016; Virtanen, 2018). For example, researchers generally have focused on OJ dimensions (distributive, procedural, interpersonal, and informational justices) impact on number of employees' attitudes and behavior. While contemporary researchers recommend a shift in focus from OJ dimensions to overall OJ, as it provides complete understanding and is more proximal to employees' attitudes and relevant behavior (Ambrose \& Griffth, 2015; Ambrose \& Arnaud, 2005; Ambrose \& Schminke, 2009).

In this connection, many researchers' have used overall justice as a mediator between OJ 
dimensions and different kinds of employees' attitudes and behavior; however, their results are not consistent. For example, Jones and Martens (2009) found that only DJ and INPJ have significant impact on overall justice relative to PJ and INFJ. While some researchers reported that all dimensions have significant impact on overall OJ (Patel et al., 2012). Ambrose and Schminke (2009) has empirically tested this assumption. They used two studies to test the aforementioned assumption. Their first study reflects that dimensions of OJ have significant impact on overall justice; however, in second study, DJ have no impact on overall justice. Similarly, this assumption was also evaluated by other researchers (Holtz and Harold, 2009). They found that all dimensions have significant impact on overall OJ.

Researchers in the area of human resource management and organizational psychology generally accept that there exist multiple types/levels of attitudes, however organizational behavior focuses on work-related attitudes only (Robbins \& Judge, 2013). Further, the literature in human resource management gives more attention to some attitudes, such as, organizational commitment (OC), job involvement (JI), and job satisfaction (JS) (Robbins \& Judge, 2013). To evaluate the mediating mechanism of overall justice, this study has used OC as an employee's attitude.

This study pursues following objectives.

1. To determine the level of prevalence of $\mathrm{OJ}$ dimensions within private sector universities, operating in Pakistan.

2. To evaluate the mediating mechanism of overall justice between OJ dimensions and OC.

\section{Review of Literature}

The term justice was initially coined by eminent researchers, such as, Kant, Augustine, Aristotle, Plato, and Aquinas. Justice implies to perceived acceptance of rules and procedures that specify relevance in decision making context (Graso, Camps, Strah, \& Brebels, 2020). The construct of justice has been developed up to the level that its four dimensions are commonly recognize in literature (Colquitt \& Shaw, 2005). The four dimensions, according to literature are: procedural justice (PJ), informational justice (INFJ), distributive justice (DJ), and interpersonal justice (INPJ) (Khan, Sheraz \& Maher, 2018, Marzucco et al, 2014).

\subsection{Distributive Justice (DJ)}

DJ deals with distribution of resources, which consists of rewards, benefits, promotions, and pay etc. Employees compare their inducements and contributions, with that of other employees working within organization or outside on the same pay scale. When employees evaluate that their inducements are unfair than they may leads to perception of unfair treatment (Adam, 1965). Three sub-dimensions of DJ are: (1) equity theory (Adam, 1965), (2) equality, and (3) need (Khan, Sheraz \& Maher, 2018; Alzayed, Jauhar \& Mohaidin, 2017).

\subsection{Procedural Justice (PJ)}

PJ deals with processes and procedures while making important decisions regarding employees. It is the perception of employees pertaining to the fairness of the process and procedures while taking important decision regarding them. When employees perceived that process or procedure have not been properly implemented by managers to reach the decisions than they may lead to the perception of unfair treatment (Leventhal, 1980). Similarly, contemporary researchers also agree that it is the level to which rules, procedures, and processes are adapted and executed by management of an organization for their HRM related activities (Pakpahan, 2018).

Thibaut \& Walker (1975) initially identified two criteria for PJ, which include: (1) process control 
and (2) decision control. Leventhal (1980) expanded this list to six procedures, which include: (1) consistency, (2) bias compression, (3) accuracy of information, (4) correctability, (5) representation, and (6) ethicality. Recent research also referred the aforementioned criteria of PJ (Kaur \& Bedi, 2017; Khan, Sheraz \& Maher, 2018).

\subsection{Interpersonal Justice (INPJ)}

INPJ deals with how employees receive treatment from their immediate supervisor. It is the extent to which employees are treated by managers with dignity and respect (Colquitt, 2001). When employees perceived that they are not treated well than they may lead to perceptions of unfair treatment (Colquitt, 2001). This definition is based on earlier conceptualization of interactional justice (Bies \& Moag, 2001; Greenberg, 1993); however, Colquitt (2001) divide interactional justice into INPJ, and INFJ.

\subsection{Informational Justice (INFJ)}

Colquitt (2001) introduced this dimension and define it as the extent to which information is communicated to employees well on time and are correct. When employees perceive that information was not shared well on time, or it is inaccurate than they lead to perceptions of unfair treatment. This dimension was introduced on the basis of earlier conceptualization of (Bies \& Moag, 1986; \& Greenberg, 1993). Bies \& Moag (1986) criteria of interactional justice include two elements of INFJ, namely, truthfulness, and justification. However, this criterion was expanded to information must be timely, reasonable, and specific (Shapiro, Buttner, \& Barry 1994).

\subsection{Overall Justice (OJ)}

Ambrose \& Schminke (2009) have empirically verified that between OJ dimensions and employees' attitudes, such as, job satisfaction, and OC, overall justice mediates They have employed two different data set to test the mediating mechanism of overall justice. The empirical results of their first data set show that all dimensions of OJ have significant contribution in overall justice; however, in second data set, three dimensions significantly contribute towards overall justice, with the exception of overall justice. The concept of overall justice was proposed by Lind (2001) and Virtanen (2018), who stated that when employees receive information regarding justice then they evaluate it and form overall OJ perception. He along with his other colleague further stated that individual OJ dimension does not give us complete understanding of employees' justice experiences rather employees make overall perception of justice within organization (Lind \& Van den bos, 2002). Similarly, this assumption was also tested by Jones and Martens (2009), they reported that first two dimensions, namely, DJ and INPJ significantly contribute relative to PJ and INFJ. Hence, we assume that overall justice between OJ dimensions and OC.

\subsection{Relationship between OJ dimensions and Commitment}

Colquitt et al. (2001) conducted a comprehensive meta-analysis and found that distributive and procedural justices have significant relationship with organizational commitment. Similarly, Robbins (2013) also found association between different types of justice, such as, distributive, and procedural with organizational commitment. Consistent to the earlier studies, Lambert et al (2003) reported that procedural and distributive justices are the key determinants of organizational commitment. However, some researchers also reported that there is no relationship between organizational justice and commitment (Griffin and Hepburn, 2005).

Zaman, Ali and Ali (2010) reported that procedural justice and distributive justice have positive and significant effect on commitment. Bakhshi, Kumar and Rani (2009) have earlier also found that 
there exist positive relationships between procedural and distributive dimension of justice with organizational commitment. Moreover,

Ponnu and Chuah (2010) have also studied the relationship between different dimensions of justice and organizational commitment. They also reported positive and significant relationship between abovementioned constructs.

Fatt et al. (2010) observed that distributive justice and procedural justice have significant relationship with organizational commitment. Furthermore, Bakhshi, Kumar and Rani (2009) also reported that distributive justice and procedural justice are the key determinants of organizational commitment. In this context, McFarlin and Sweeney (1992) have also found that distributive and procedural justice dimensions are significant factor affecting organizational commitment. More contemporary researchers like, Najafi et al. (2011) also found that different types of organizational justice significantly predict employee's organizational commitment.

\section{Research Hypotheses}

$\mathrm{H}_{1}$ : OJ dimensions significantly affect overall OJ.

$\mathrm{OJ}=\mathrm{f}(\mathrm{PJ}, \mathrm{DJ}, \mathrm{INPJ}, \mathrm{INFJ}) \quad$ (Model NO. 1)

$\mathrm{H}_{2}$ : Overall OJ mediate between OJ dimensions and OC.

$$
\mathrm{OC}=\mathrm{f}(\mathrm{PJ}, \mathrm{DJ}, \mathrm{INPJ}, \mathrm{INFJ}, \mathrm{OJ}) \quad \text { (Model NO. 2) }
$$

\section{Research Methodology}

The proposed research, discussed in previous sections requires respondent feedback pertaining to OJ dimensions, overall OJ, and OC. This necessitates survey approach to data collection.

\subsection{Survey Approach}

A survey was conducted to collect data from faculty members pertaining to OJ dimensions, overall OJ, and OC. In survey approach, faculty members were required to rate existing prevailing conditions regarding OJ dimensions, overall OJ and its impact on OC. In this connection, a four dimensions questionnaire was adapted from (Colquitt, 2001). Similarly, for overall OJ, a questionnaire of Ambrose \& Schminke (2009) was adopted. While for OC, we adopted Mowday, Steers \& Porter (1982) questionnaire.

\subsection{Population}

Faculty members working in private sector universities of management sciences department, within Pakistan will be the population for this study. At least nine faculty members from each university were selected to collect data for the purpose of this study ( $9 * 44=396)$. Therefore, the target size for data collection was 483 .

\subsection{Data Analysis}

Kenny (2012) mediation analysis was used to analyze data regarding all three constructs. This approach of analysis was specifically selected to test the hypotheses of this study by using SPSS 21 version.

\section{Results and Discussion}

This section deals with results, interpretation, and discussion of the statistical analysis. The researcher distributed 396 questionnaires among the faculty members. The researcher received back 
314 questionnaires. Out of 314 questionnaires, o8 were not considered for the result either because of the missing of the relevant dependent variables or independent variables data. Likewise, because of the extreme lowest values which were creating the normality problem, the four respondents' data was also dropped. Hence, the definitive sample size for testing stood at 302 questionnaires, establishing a response rate of 75 percent.

\subsection{Descriptive statistics}

Table 1 reflects the descriptive statistics of faculty members in terms of their gender, age, education level, experience, and designation.

Table 1: Descriptive statistics of faculty members

\begin{tabular}{|c|c|c|}
\hline Variables & Count & Percentage \\
\hline \multicolumn{3}{|l|}{ 1. Gender } \\
\hline Male & 187 & 61.92 \\
\hline Female & 115 & 38.08 \\
\hline Total & 302 & 100 \\
\hline \multicolumn{3}{|l|}{ 2. Age } \\
\hline $24-29$ & 159 & 52.65 \\
\hline $30-34$ & 63 & 20.86 \\
\hline $35-40$ & 35 & 11.59 \\
\hline $40-44$ & 19 & 6.29 \\
\hline $45-49$ & o8 & 2.65 \\
\hline 50 \& above & 18 & 5.96 \\
\hline Total & 302 & 100 \\
\hline \multicolumn{3}{|l|}{ 3. Experience } \\
\hline $1-5$ years & 196 & 64.90 \\
\hline 6-10 years & 78 & 25.82 \\
\hline 11-15 years & 15 & $4 \cdot 97$ \\
\hline 16-20 years & 07 & 2.32 \\
\hline $21 \&$ above & 6 & 1.99 \\
\hline Total & 302 & 100 \\
\hline \multicolumn{3}{|l|}{ 4. Designation } \\
\hline Lecturer & 195 & 64.57 \\
\hline Assistant Professor & 73 & 24.17 \\
\hline Associate Professor & 18 & 5.96 \\
\hline Professor & 16 & $5 \cdot 30$ \\
\hline Total & 302 & 100 \\
\hline \multicolumn{3}{|l|}{ 5. Education } \\
\hline Master & 18 & 5.96 \\
\hline MS/MPhil Degree & 174 & 57.62 \\
\hline PhD Degree & 110 & 36.42 \\
\hline Total & 302 & 100 \\
\hline
\end{tabular}

Table 1 shows that $61.92 \%$ of our respondents were male; while, remaining $38.08 \%$ were 
female. Further, a large majority of our respondents were lecturers (64.57\%), followed by assistant professor $(24.17 \%)$; while associate professors (5.96\%) and professors (5.30\%) are least represented in this sample. Likewise, $(57.62 \%)$ of our respondents have MS/MPhil degree, $(36.42 \%)$ have PhD Degree and the remaining $(5.96 \%)$ have master's degree. Our results further reflect that faculty members having 1-5 years of experience are significantly (64.90\%) represented in the sample; and they are under the age bracket of 24-29 years.

\subsection{Reliability analysis and Multicollinearity detection}

Table (2) provides the Cronbach's alpha and correlations coefficient of dimensions of OJ. The respondent's feedbacks were evaluated for reliability through SPSS on all six dimensions. The measures show good results as the reliability results of our all six constructs are near to one.

Table 1: Correlation coefficient \& Cronbach's alpha

\begin{tabular}{|l|l|l|l|l|l|l|l|l|l|}
\hline Construct & A & M & S. D & $\mathbf{1}$ & $\mathbf{2}$ & $\mathbf{3}$ & $\mathbf{4}$ & $\mathbf{5}$ & $\mathbf{6}$ \\
\hline DJ & 0.957 & 3.41 & 0.869 & 1 & & & & & \\
\hline PJ & 0.948 & 3.79 & 0.929 & 0.087 & 1 & & & & \\
\hline RPJ & 0.959 & 3.89 & 0.889 & -0.036 & $0.500^{*}$ & 1 & & & \\
\hline INPJ & 0.948 & 4.10 & 0.719 & -0.045 & $0.413^{*}$ & $0.389^{*}$ & 1 & & \\
\hline INFJ & 0.926 & 4.08 & 0.604 & -0.076 & $0.405^{*}$ & $0.419^{*}$ & $0.391^{*}$ & 1 & \\
\hline OJ & 0.888 & 4.06 & 0.586 & -0.024 & $0.488^{*}$ & $0.464^{*}$ & $0.450^{*}$ & $0.728^{*}$ & 1 \\
\hline
\end{tabular}

*. Correlation is significant at the 0.01 level.

Likewise, table (2) also demonstrate that the correlation coefficients are extremely substantial but not too strong, except for overall OJ and INFJ; however, it is still in tolerable limit. Thus, it can be concluded that the problem of multicollinearity is not present in our model based on correlation test.

Table 2: Impact of OJ dimensions on overall OJ

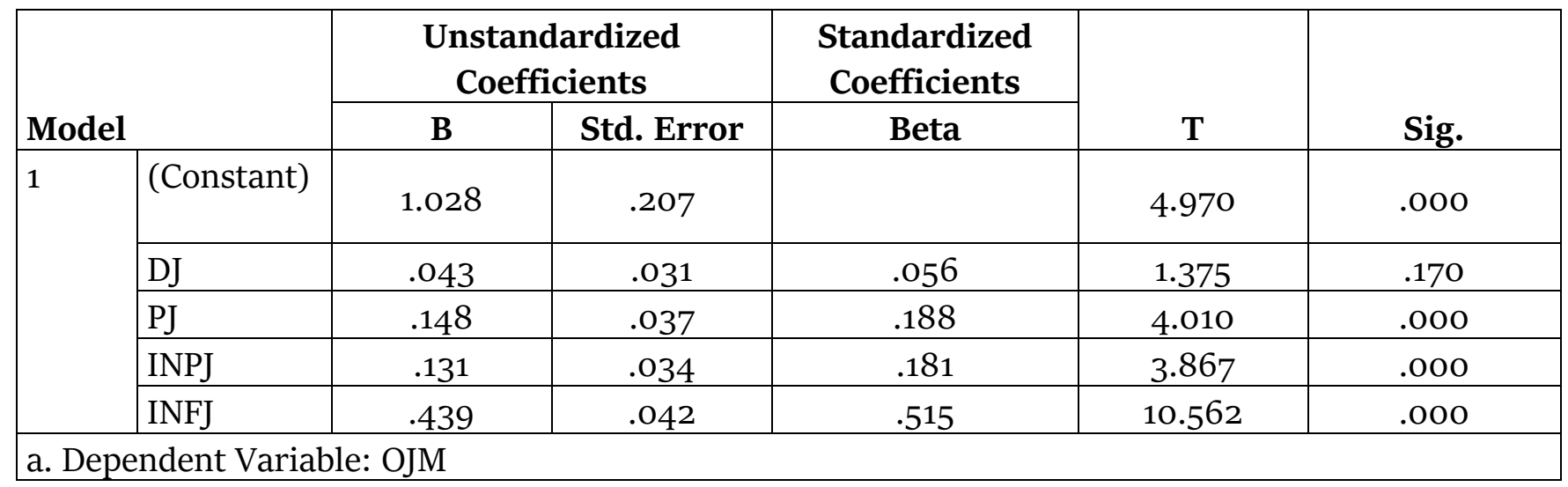

$\mathrm{F}=82.090(\mathrm{p}=0.000), \mathrm{R}^{2}=0.532$

Table (1) shows that $\mathrm{F}=82.09$, ( $\mathrm{p}<0.01$ ) suggest that overall model is statistically significant, and $\mathrm{R}^{2}=.532$ means that $53 \%$ variation in our dependent variable overall OJ is mainly due to our independent variables (DJ, PJ, INPJ, and INFJ). The results of our independent variable reflect that with 
the exception of DJ variable ( $b_{1}=0.043, p>0.05$ ), all other variables have statistically significant impact on overall OJ. INFJ variable has slightly greater impact (b4 $=0.439, \mathrm{p}<0.005$ ), as compared to PJ (b2 = 0.148, p < 0.005), and INPJ (b3 = 0.131, p < 0.005). As, three out of four variables have significant impact on overall OJ; therefore, hypotheses $\mathrm{H} 1$ is partially accepted.

\section{Table 3: Impact of OJ dimensions and overall OJ on OC}

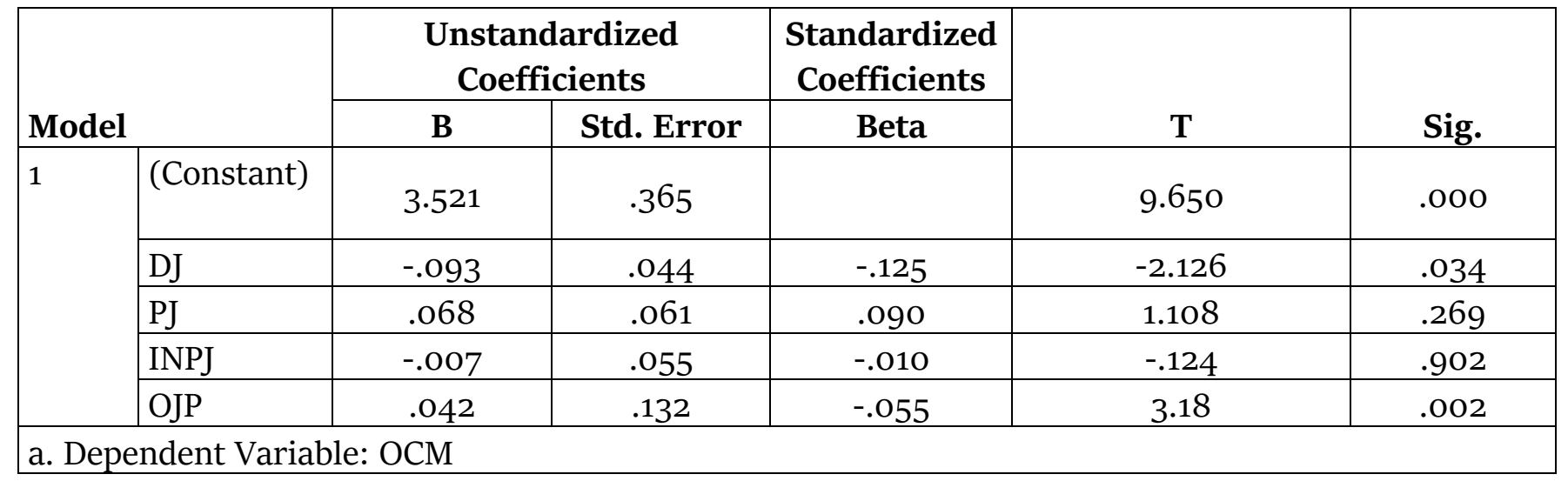

$\mathrm{F}=3.420(\mathrm{p}=0.227), \mathrm{R}^{2}=0.019$

Table 2 measures the mediating effect between OJ dimensions and OC, as suggested by eminent researchers (Ambrose \& Schminke, 2009). Contemporary approach of mediation was employed to test the mediating effect of overall OJ (Kenny, 2012). Table (2) shows the empirical results of OJ dimensions along with predicated value of overall OJ on OC. F $=3.420, p<0.05$, indicate that our model (2) is statistically significant. $\mathrm{R}^{2}=.019$ reflect that very small variation in OC which is a dependent variable, and it is due to our independent variable, PJ, DJ, INPJ, and predicated value of OJ. While, INFJ has been dropped from our model because of high multicollinearity.

T-statistics and p-values of independent variables shows that except for DJ; other variables turn out to be insignificant. The first variable (DJ) has significant impact $\left(b_{1}=-0.093, \mathrm{p}<0.005\right)$ on OC, while other two independent variables have insignificant impact $\left(b_{2}=0.068, \mathrm{p}>0.005, b_{3}=0 .-007, \mathrm{p}\right.$ $>0.005$, ) whereas our mediator variable overall OJ also have significant impact on OC $\left(b_{4}=0.042, \mathrm{p}<\right.$ 0.05), which satisfies the requirements of mediation.

According to mediation's requirements. With the inclusion of over mediator variables, the effects of DJ, PJ, \& INPJ variables have changed from $b_{1}=0.043, b_{2}=0.0148$, and $b_{3}=0.131$, (table 1 ) to $\beta_{1}=-$ 0.093, $\beta_{2}=0.068$, and $\beta_{3}=0 .-007$, (table 2), respectively. While, INFJ has been dropped from our model because of high multicollinearity.

These results reflects that our mediator variable satisfies the requirements of mediation analysis, and as other independent variables are insignificant, so we may conclude that OJ is largely mediating.

\section{Discussion \& Conclusion}

The first objective of this paper was to determine the level of prevalence of OJ dimensions within private sector universities, operating in Pakistan. Our results reflect that that with the exception of DJ, remaining three variables (PJ, INPJ, and INFJ) have significant impact on overall justice. These results suggest that three dimensions of OJ (PJ, INPJ, and INFJ) prevails in private sector universities of Pakistan. These results support the previous studies that the that the emphasis of individual 
organizational dimension might not depict the exact image of employee's justice experiences (Ambrose \& Arnaud, 2005; Lind \& van den Bos, 2002). Similarly, our second objective was to evaluate the mediating mechanism of overall justice between dimensions of OJ and OC. Pertaining to second objective, our findings shows that overall justice fulfils the conditions of mediation analysis, and as per the criterion of mediation analysis some independent variables turnout to be insignificant after incorporation of mediating variable, so we may conclude that OJ is largely mediating. So, based on our empirical results we can say that there is no direct relationship between OJ dimensions and OC; rather, this relationship is best explained by incorporating overall justice as mediating variable. These results are in line with previous studies where the researchers found that one specific justice dimension did not show significant relationship with OC (Ponnu \& Chuah, 2010; Ambrose \& Schminke, 2009; Jones \& Martens, 2007). Additionally, focusing on overall justice can provide a more complete picture of how justice influences other organizational phenomena (Ambrose \& Arnaud, 2005; Colquitt, Greenberg, \& Scott, 2005).

This research contributes to the existing literature by pointing out one additional dimension into the model and additionally recommends that upcoming research studies need to investigate and explore OJ dimensions and assess their contribution towards overall OJ. The measure used in this study should be further replicated to confirm the results. Future research needs to identify how the five types of organizational justice can be efficiently and effectively executed in both public and private sector universities. This study therefore contributes to the literature by developing a relatively complete organizational justice measure, which would help to better understand the justice experiences of the employees and their appropriate attitude and behavior towards them. The measure used in this study should be replicated in other sectors to validate the results and findings of this research study. Future research should therefore focus on the employees' experiences of overall justice to capture the exact picture within the organizations.

\section{References}

Adams, J. S. (1965). Inequity in social exchange. Advances in experimental social psychology. 2: 267299.

Alzayed, M., Jauhar, J., \& Mohaidin, Z. (2017). The Mediating Effect of Affective Organizational Commitment in the Relationship between Organizational Justice and Organizational Citizenship Behavior: A Conceptual Model. Asian Social Science, 13(5), 165. doi: 10.5539/ass.v13n5p165

Ambrose, J. L., Wo, D. X. H., \& Griffith, M. D. (2015). Overall justice: Past, present, and future. In R. S. Cropanzano \& M. L. Ambrose (Eds.). The Oxford handbook of justice in the workplace (Vol. 1, pp. 109-135). New York: Oxford University Press.

Ambrose, M. L., \& Arnaud, A. (2005). Distributive and procedural justice: Construct distinctiveness, construct interdependence, and overall justice. In J. Greenberg \& J. Colquitt (Eds.), the handbook of organizational justice (pp. 59-84). Mahwah, NJ: Erlbaum.

Ambrose, M.L., \& Schminke,M. (2009). The role of overall justice judgements in organizational justice research: A test of mediation. Journal of applied psychology. 94(2): 491-500

Bakhshi A, Kumar K and Rani E (2009). Organizational Justice Perceptions as Predictor of Job Satisfaction and Organization Commitment. International Journal of Business and Management, 4 (9), 145-154.

Bies, R. J. (2001). Interactional (in)justice: The sacred and the profane. In J. Greenberg \& R. Cropanzano (Eds.), Advances in organizational justice: 85-108. Stanford, CA: Stanford University Press.

Bies, R. J., and Moag, J. F. (1986). Interactional justice: Communication criteria of fairness. In R. J. Lewicki, B. H. Sheppard, \& M. H. Bazerman (Eds.). Research on negotiations in organizations. 1: 
43-55.

Colquitt J. A., Rodell J. B. (2015). Measuring justice and fairness. In The Oxford Handbook of Organizational Justice, Vol. 1, ed. R Cropanzano, ML Ambrose. New York: Oxford Univ. Press. In press

Colquitt, J. A. (2001). On the dimensionality of organizational justice: A construct validation of a measure. Journal of Applied Psychology, 86: 386-400.

Colquitt, J. A. (2012). Organizational justice. Oxford Handbook of Organizational Psychology, 1:526-547.

Colquitt, J. A., \& Shaw,J. C. (2005). How should organizational justice be measured? In J. Greenberg \& J. A. Colquitt (Eds.), the handbook of organizational justice (pp. 113-152). Mahwah, NJ: Erlbaum.

Colquitt, J. A., Conlon, D. E., Wesson, M. J., Porter, C. O. L. H., \& Ng, K. Y. (2001). Justice at the millennium: A meta-analytic review of 25 years of organizational justice research. Journal of Applied Psychology, 86: 425-445.

Colquitt, J. A., Scott, B. A., Rodell, J. B., Long, D. M., Zapata, C. P., Conlon, D. E., \& Wesson, M. J. (2013). Justice at the millennium, a decade later: A meta-analytic test of social exchange and affectbased perspectives. Journal of Applied Psychology, 98, 199-236. doi:10.1037/aoo31757

Colquitte, J. A., Greenberg, J., and Scott, B.A. (2005). Organizational justice: where do we stand? In J. Greenberg and J.A Colquitt (Eds.) handbook of organizational, Mahwah: NJ: Lawrence Erlbaum Associate. 589-619.

Fatt C.K, Sek Khin E.W and Heng TN (2010). The Impact of Organizational Justice on Employee's Job Satisfaction: The Malaysian Companies Perspectives. American Journal of Economics and Business Administration 2 (1): 56-63.

Graso, M., Camps, J., Strah, N., \& Brebels, L. (2020). Organizational Justice enactment: An agent focused review and path forward. Journal of Vocational Behaviour, 116, 103296.

Greenberg, J. (1993). The social side of fairness: Interpersonal and informational classes of organizational justice. In R. Cropanzano (Ed.), Justice in the workplace: Approaching fairness in human resource management (pp.79-103). Hillsdale, NJ: Erlbaum.

Holtz, B. C., \& Harold, C. M. (2009). Fair today, fair tomorrow? A longitudinal investigation of overall justice perceptions. Journal of Applied Psychology, 94, 1185-1199.

Jones, D. A. and Martens, M. L. (2009). The mediating role of overall fairness and the moderating role of trust certainty in justice-criteria relationships: the formation and use of fairness heuristics in the workplace. J. Organizational Behavior, 30: 1025-1051. doi: 10.1002/job.577

Kaur, S., \& Bedi, A. (2017). Role of Perceived Organizational Support in the Relationship of Procedural Justice with Organizational Commitment. Prabandhan: Indian Journal of Management, 10(9), 28. doi: 10.17010/pijom/2017/v10i9/118240

Kenny, D. A. (2012). Mediation; available on: davidakenny.net, April 2012.

Khan, J. A., Sheraz, M., \& Maher, S. (2018). Impact of organizational justice on organizational commitment: Evidence from KPK private sector Universities. City university research journal, 8 (2)- 236-246.

Lambert, E. G. (2003). The impact of organizational justice on correctional staff. Journal of Criminal Justice, 31(2), 155-168. https://doi.org/10.1016/s0047-2352(02)00222-2

Leventhal, G. S. (1980). What should be done with equity theory? New approaches to the study of fairness in social relationships. In K. Gergen, M. Greenberg, \& R. Willis (Eds.), Social exchange: Advances in theory and research (pp. 27-55). New York: Plenum Press.

Leventhal, G. S., Karuza, J., \& Fry, W. R. (1980). Beyond fairness: A theory of allocation preferences. In G. Mikula (Ed.). Justice and social interaction. New York: Springer- Verlag 167-218.

Lind, E. A. (2001). Fairness heuristic theory: Justice Judgments as pivotal cognitions in organizational relations. In Advances in organizational justice (56-88) J. Greenberg, \& R. Cropanzano (Eds.), CA: Stanford University Press. 
Lind, E. A., \& van den Bos, K. (2002). When fairness works: Toward a general theory of uncertainty management. In B. M. Staw \& R. M. Kramer (Eds.), Research in organizational behavior (Vol. 24, pp. 181-223). Boston: Elsevier.

Marie L. Griffin, John R. H. (2005). Side-bets and reciprocity as determinants of organizational commitment among correctional officers, Journal of Criminal, 33(6).

Marzucco, L., Marique, G., Stinglhamber, F., De Roeck, K., \& Hansez, I. (2014). Justice and employee attitudes during organizational change: The mediating role of overall justice. European Review of Applied Psychology, 64(6), 289-298.

McFarlin, D. B., \& Sweeney, P. D. (1992). Distributive and procedural justice as predictors of satisfaction with personal and organizational outcomes. Academy of Management Journal, 35(3), 626-637.

Mowday, R., Porter, L., \& Steers, R. (1982). Employee organization linkages: The psychology of commitment, absenteeism, and turnover. New York, NY: Academic Press.

Najafi, S., Noruzy, A., Azar, H. K., Nazari-Shirkouhi, S., \& Dalvand, M. R. (2011). Investigating the relationship between organizational justice, psychological empowerment, job satisfaction, organizational commitment, and OCB: An empirical model. African Journal of Business Management, 5(13), 5241-5248.

Pakpahan, B. (2018). The impact of organizational culture, conflict management, and procedural justice towards normative commitment of human resource at Stakpn Tarutung. International Journal of English Literature and Social Sciences, 3(2), 174-180. doi: 10.22161/ijels.3.2.8

Patel, C., Budhwar, P., \& Varma, A. (2012). Overall justice, work group identification and work outcomes: test of moderated mediation process. Journal of world business, 47: 213-222.

Ponnu, C.H. and Chuah, C.C. (2010) Organizational commitment, organizational justice and employee turnover in Malaysia. African Journal of Business Management, 4 (13). pp. 2676-2692.

Robbins, S. P., \& Judge, T. A. (2013). Organizational behavior. Pearson education, Inc.

Rupp, D. E., \& Spencer, S. (2006). When customers lash out: The effect of customer interactional injustice on emotional labor and the mediating role of discrete emotions. Journal of Applied Psychology, 91: 971-978.

Rupp, D. E., Shapiro, D. L., Folger, R.,Skarlicki, D, P., \& Shao, R. (2017). A Critical Analysis of the Conceptualization and Measurement of 'Organizational Justice': Is it Time for Reassessment?” Academy of Management Annals. 1-82.

Shah, A, U., \& Khan, M, I. (2019). HRM-Performance Perspectives: An Overview of Theoretical Challenges and Prospects. Inzinerine Ekonomika-Engineering Economics, 30(3), 382-393.

Shapiro, D. L., Buttner, E. H., and Barry, B. (1994). Explanations: What factors enhance their perceived adequacy? Organizational behavior and human decision processes. 58: 346-368.

Thibaut, J., \& Walker, L. (1975). Procedural justice: A psychological analysis. Hillsdale, NJ: Erlbaum.

Virtanen, M., \& Elovainio, M. (2018). Justice at the workplace. Cambridge Quarterly of Healthcare Ethics, 27, 306-315.

Zaman, G., Ali, N., \& Ali, N. (2010). Impact of Organizational justice on employees' outcomes: An Empirical Evidence. Abasyn Journal of social sciences, 3(1), 44-53. 